\title{
Wave run-up on embayed beaches. Study case: Itapocorói Bay, Southern Brazil
}

\author{
Guilherme Vieira da Silva ${ }^{*}$, Paula Gomes da Silva², Rafael Sangoi Araujo ${ }^{3}$, Antonio Henrique da \\ Fontoura Klein ${ }^{4}$, Elírio E. Toldo Jr. ${ }^{5}$
}

${ }^{1}$ Griffith Centre for Coastal Management (GCCM) - Griffith University

(Gold Coast Campus - QLD 4222 - Building location (G51) Australia).

${ }^{2}$ Instituto de Hidráulica Ambiental (IH Cantabria) - Universidad de Cantabria

(Parque Científico y Tecnológico de Cantabria, C/ Isabel Torres, 15, 39011 Santander, Cantabria, Cantabria, Espanha)

${ }^{3}$ Centro de Ciências Tecnológicas da Terra e do Mar (CTTMar) - Universidade do Vale do Itajaí

(Rua Uruguai, 458, Centro - Itajaí - Santa Catarina, CEP 88302-901)

${ }^{4}$ Laboratório de Oceanografia Costeira (LOC) -Departamento de Geociências Universidade Federal de Santa Catarina

(Campus Universitário Trindade - Florianópolis - SC - Brasil. CEP: 88040-900)

${ }^{5}$ Centro de Estudos de Geologia Costeira e Oceânica (CECO) - Universidade Federal do Rio Grande do Sul

(Campus do Vale Av. Bento Gonçalves, 9500 - Porto Alegre - RS - Brasil CEP: 91501-970)

*Corresponding author: g.vieiradasilva@griffith.edu.au

\section{ABSTRACT}

This paper presents a new approach for estimating run-up on embayed beaches based on a study of the microtidal coast of Itapocorói Bay, Southern Brazil using the surf similarity parameter and wave height at break location. The four step methodology involved: 1) direct wave measurement (34 days), wave run-up measurement (19 days at 7 points within the bay), measurement of bathymetry and beach topography in the entire bay; 2) tests on available formulae to calculate wave run-up; 3) use of the SWAN spectral wave model to simulate wave parameters at breaking at each wave run-up measurement point and; 4) development of a new formula/approach to assess wave run-up on embayed beaches (in both exposed and protected areas). During the experiments the significant wave height varied from $0.5 \mathrm{~m}$ to 3.01 $\mathrm{m}$, the mean wave period from $2.79 \mathrm{~s}$ to $7.76 \mathrm{~s}$ (the peak period varied between $2.95 \mathrm{~s}$ and $17.18 \mathrm{~s}$ ), the mean wave direction from $72.5^{\circ}$ to $141.9^{\circ}$ (the peak direction varied from $39.2^{\circ}$ to $169.8^{\circ}$ ) and the beach slope $(\tan \beta$ ) from 0.041 to 0.201 . The proposed formula is in good agreement with measured data for different wave conditions and varying degrees of protection. The analysis demonstrates that although $\mathrm{R}^{2}$ varies from 0.52 to 0.75 , the wave run-up distribution over the measurements agreed well with the proposed model, as shown by quantile-quantile analysis $\left(\mathrm{R}^{2}=0.98\right.$ to 0.99$)$. The errors observed in individual cases may be related to errors of measurements, modeling and to non-linear processes in the swash zone, such as infragavity waves.

Descriptors: Swash zone, Overtopping, Coastal management, Coastal inundation, Beach erosion, Coastal process.

Submitted on: 04/08/2016

Approved on: 10/02/2017

http://dx.doi.org/10.1590/S1679-87592017133706502

\section{RESUMO}

Este artigo tem o objetivo de estimar o run-up em praias de enseada a partir de estudo realizado na Enseada do Itapocorói, localizada em uma costa de micromarés no sul do Brasil utilizando o parâmetro de similaridade de surf (surf similarity parameter) e altura de ondas no ponto de quebra. A metodologia aplicada foi dividida em quatro etapas: 1) medição direta de ondas (34 dias), medidas de wave run-up (19 dias em 7 pontos da baía), medições topo-batimétricas; 2) testes com as fórmulas disponíveis na literatura para cálculo do run-up; 3) uso do modelo espectral SWAN para simular a propagação das ondas e obter os parâmetros de ondas no ponto de quebra no momento das medições do run-up e; 4) desenvolvimento de uma nova abordagem para estimar o run-up em praias de enseada (aplicável às áreas protegidas e expostas da enseada). Os resultados demonstram que, durante os experimentos, a altura significativa de onda variou entre 0,5 e $3,01 \mathrm{~m}, \mathrm{o}$ período médio entre 1,79 e 7,76 s (o período de pico entre 2,95 e 17,19 s), a direção média entre $72,5^{\circ}$ e $141,9^{\circ}$ (a direção de pico entre $39,2^{\circ}$ e $169,8^{\circ}$ ) e a declividade da face da praia $(\tan \beta)$ entre 0,041 e 0,201 . A fórmula proposta apresenta boa concordância com os dados medidos para diferentes condições de ondas e graus de proteção da praia. Como conclusão destaca-se que, apesar do $\mathrm{R}^{2}$ variar entre 0,52 e 0,75 , a distribuição das medições de run-up apresentou boa concordância com o modelo proposto, como demonstrado pela análise quantil-quantil $\left(\mathrm{R}^{2}=0,98\right.$ a 0,99$)$. Os erros observados em casos individuais podem estar relacionados a erros das medições, do modelo e aos processos não lineares presentes na zona de espraiamento, como as ondas de infragravidade.

Descritores: Zona de espraiamento, Sobrelavagem, Gerenciamento costeiro, Inundação costeira, Erosão praial, Processos costeiros. 


\section{INTRODUCTION}

The run-up induced by waves on natural beaches and artificial structures has been the focus of many studies over the last few decades (e.g. AHRENS; TITUS, 1985; NIELSEN, 1989; HOLLAND et al., 1995; LONGO et al., 2002; BONETTI et al., 2012), since it is an important criteria for the design of coastal structures and an important element in analysis of vulnerability to erosion and flooding at the coast (HOLMAN; SALLENGER, 1985). Furthermore, run-up in the swash zone is an important boundary condition for numerical models of beach evolution (HORIKAWA, 1988). Described as the maximum height above sea water level reached on the coastline (BATTJES; JANSSEN, 1978), the run-up is composed of a superelevation of the mean water level caused by breaking waves (setup) and of fluctuations around this superelevation on the beach (swash) (GUZA; THORTON, 1982; HOLMAN; SALENGER, 1985).

Due to the complexity of the non-linear processes involved in run-up generation, its prediction is often based on empirical approaches (BATTJES, 1974; HEDGES; MASE, 2004) and shall be based on parameters that represent all the wave transformation processes, until it reaches the beach and/or structure. Nevertheless, for pragmatic reasons, most studies undertake run-up predictions based only on the beach or structure slope and deep water wave parameters as wave height and wave length (NIELSEN; HANSLOW, 1991).

The primary efforts on calculating run-up through empirical parametrizations was presented by HUNT (1959), based on data obtained from laboratory experiments that represented the run-up of monochromatic waves over structures with flat and impermeable bottoms. The author proposed that run-up was related to the structure slope, wave height and wave length, through the surf similarity parameter $(\xi)$. The formulation given by HUNT (1959) has been heavily utilized, however, applying formulas based on laboratory data to natural beaches can present some complications, as stated by STOCKDON et al. (2006): i) in natural conditions wave height and period become statistical parameters (usually significant wave height (Hs) and peak period (Tp)); ii) the wave height is measured at different points (deep water wave height, break height, local height) and iii) defining only one value of beach slope to describe the run-up on the entire beach is difficult and becomes more complicated in the presence of sandbars.
Since then, several authors presented run-up formulations based on data from natural beaches. GUZA; THORTON (1982) used data from a field experiment to define a formulation relating wave height at a point in 10 $m$ depth and the elevation of run-up on an exposed sandy beach. The authors justify the absence of correlation with the surf similarity parameter by the low range of $\xi_{0}$ in their data.

NIELSEN; HANSLOW (1991) tested the run-up on natural sandy beaches with different slopes. They analyzed run-up on six exposed beaches (from dissipative to reflective conditions) relating it to the values of wave height at a point in $80 \mathrm{~m}$ water depth and the beach face slope. Assuming a Rayleigh distribution, the authors presented the results for different statistics run-up (mean run-up, significant run-up, run-up exceeded by $2 \%$ of the waves, run-up exceeded by $1 \%$ of the waves and root mean squared run-up). According to analysis of the data collected in that work, the beach slope has no significant influence on the values of run-up height on beaches with low beach face slopes $(\tan \beta<0.1)$.

RUGGIERO et al. (2004) conducted tests using data from video monitoring and field campaigns on a high-energy dissipative beach (Agatha Beach), in Oregon, USA. On beaches with these characteristics, the infragravity energy (with frequencies ranging between 0.05 and $0.004 \mathrm{~Hz}$ ) tends to dominate the inner surf and swash zones. A strong dependence was observed between run-up height variations and the beach face slope. Finally, the dependence of the surf similarity parameter was confirmed, and the results showed that it has stronger influence over run-up values when reaches values greater than 0.3 . High performance correlations using $\xi_{0}$ reflect the effect of surf zone processes and beach characteristics on run-up values, since the surfer similarity parameter is commonly used to describe and parameterize wavebreaking, amount of reflection, beach morphodynamic state, among others processes.

STOCKDON et al. (2006) used data from ten different experiments, covering the whole range of values of $\xi$. Wave parameters were obtained in shallow water and reverse shoaled until $80 \mathrm{~m}$ depth, so the data from different experiments could be compared. The run-up exceeded by $2 \%$ of the waves was related to the surf similarity parameter through an equation that calculates separately setup, incident swash $(0.05$ to $0.005 \mathrm{~Hz})$ and infragravity swash ( 0 to $0.005 \mathrm{~Hz}$ ). The results indicated that the beach face slope has no influence over the infragravity swash values, 
mainly dominant on dissipative beaches, in accordance with the findings presented by NIELSEN; HASLOW (1991). Finally, the authors tested their formulation using wave break height and found similar fit to that obtained using deep-water wave parameters. Nevertheless, the experiments were taken in exposed beaches and may not guarantee the equations' prediction capability in sheltered areas.

BONETTI et al. (2012) performed a calibration of the NIELSEN; HANSLOW (1991) model at Itapocorói Bay on Southern coast of Brazil. The work was based on wave data (at $17 \mathrm{~m}$ depth) and runup measured in different zones along an embayed beach (from exposed to sheltered zone). Through a linear regression between the run-up measured and the run-up calculated with NIELSEN; HANSLOW (1991) formula, the authors found that such parametrization better explains run-up on the exposed sectors, while lower correlation was verified in the sheltered zones. These results highlight the need of appropriate run-up predictors in zones where diffraction can be a relevant process.

Because of shallow water wave transformation around the beach boundaries, headland-bay beaches (KLEIN et al., 2010; LOUREIRO et al., 2013), show strong longitudinal gradients of wave energy, beach grain size and beach face slope. Despite of that, all formulations presented until the date (except for the site-specific calibration proposed by BONETTI et al. (2012)), are applicable to exposed beaches, but have strong limitation if applied to sheltered areas where the diffraction plays a significant role.

Based on the information presented above, it is clear that much effort was made in the past few decades to accurately predict run-up values on beaches and a large range of formulas were proposed. Even though, the lack of studies aiming to assess the run-up on sheltered areas is evident. This paper investigates the run-up on headland bay beaches using the data collected in Itapocorói Bay, Southern Brasil (same data presented by BONETTI et al., 2012). The observations were tested against existing formulations and a new empirical formulation relating run-up to wave conditions at break locations is presented. This approach is appropriate to embayed beaches where the wave attenuation present high variability alongshore.

\section{StUdy Area}

The data used in this work were collected at Itapocorói Bay, located in the central-north coast of Santa Catarina, southern Brazil, extending from Penha to Itajuba headlands (see Figure 1). The Itapocorói Bay is approximately $9 \mathrm{Km}$ long and includes Alegre (in the south, sheltered by the headland), Piçarras (central part of the bay) and Itajuba beaches (the most exposed part in the north of the bay).

At Santa Catarina coast, the waves are predominantly from the south with periods of $12 \mathrm{~s}$, followed by waves from the east with periods of $8 \mathrm{~s}$. VIEIRA DA SILVA et al (2016) demonstrate that the bimodal wave conditions are important, especially at coastlines with variable orientation. According to ARAÚJO et al. (2003) bimodal (south and east) sea conditions occur during $>30 \%$ of the time. Wave heights averages from 1 to $1.5 \mathrm{~m}$ and Ho (deep water wave height) can exceed $4 \mathrm{~m}$. During the austral autumn and winter (March to August), swell waves from south prevail over easterly seas, while in summer (December to February) there is a balance between both, and during the spring easterly seas are predominant.

Itapocory Bay presents a microtidal regime, with a predominantly semidiurnal pattern with diurnal inequalities. The mean elevation of spring tide in Santa Catarina state ranges from $0.46 \mathrm{~m}$ to $1.06 \mathrm{~m}$ (TRUCCOLO et al., 2004). Meteorological forcing can elevate water level for periods of three to ten days (CASTRO; LEE, $1995)$ with extreme values observed during winter and spring seasons. The mean elevation of storm surges is around $1 \mathrm{~m}$ (TRUCCOLO et al., 2004).

KLEIN; MENEZES (2001) classified the different sectors of the Itapocorói Bay regarding morphodynamic state and exposure to waves. According to that study, the Itapocorói Bay varies from reflective in its exposed part (Itajuba to Central) to low tide terrace in sheltered areas (Alegre). The beachface slope is around $7^{\circ}$ at Itajuba beach, $4.95^{\circ}$ at Piçarras beach and $4.6^{\circ}$ at Alegre beach. The sediments comprise fine to coarse sand, increasing in grain size northward (KLEIN; MENEZES, 2001; ARAÚJO et al., 2010).

\section{METHODS}

To assess the wave run-up on an embayed beach a methodology composed of four steps was conducted: 1) Field work to measure waves, wave run-up and beach morphology (bathymetry and topography); 2) Tests using available formulae to calculate wave run-up; 3) Assess wave parameters in front of every run-up measurement point by running and calibrating a SWAN numerical model; 4) development and validation of a new empirical formula/approach for both protected and exposed areas. 


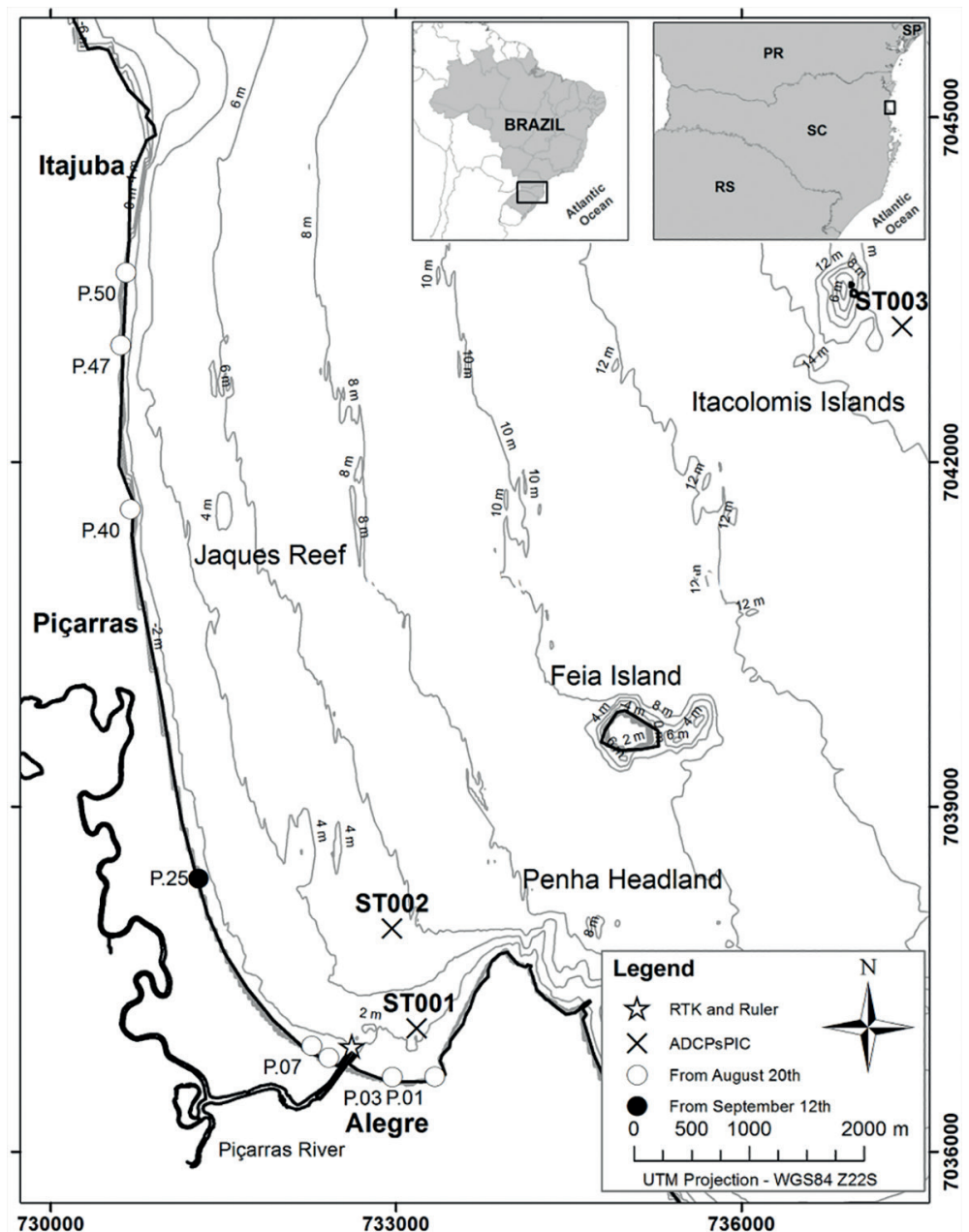

Figure 1. Location of the study area on the Southern Brazilian coastal zone. It is also indicates ADCPs (STs), wave run-up, beach profile measurement and RTK and ruler positions.

\section{Run-UP AND MORPHODYNAMIC EXPERIMENT}

A 34 day-long experiment was run to measure wave regime, wave run-up, and beach morphology. Figure 1 presents a summary of waves, wave run-up and beach profile measurement locations.

\section{WAVE MEASUREMENT}

From August $19^{\text {th }}$ to September $22^{\text {nd }}$, three ADCP Nortek $^{\mathrm{TM}}$ model AWACTM were moored at Itapocorói Bay Figure 1. Two $1 \mathrm{MHz}$ (ST001 and ST002) were moored at 3.9 and $7.3 \mathrm{~m}$ water depth, respectively and one $600 \mathrm{kHz}$ (ST003) at $16.8 \mathrm{~m}$. The equipment was installed on the seabed upward-looking and were set to measure pressure at every 30 minutes in order to establish tide data and record waves every hour with a 20 minute sample rate of 4 $\mathrm{Hz}(0.25 \mathrm{~s})$ at ST001 and ST002 and $2 \mathrm{~Hz}(0.5 \mathrm{~s})$ at ST003.
The equipment used the Acoustic Surface Tracking (AST) system that measures the actual position of the surface at high frequency leading to more accurate measurements if compared to pressure instruments.

Wave parameters (height, period and direction) and orbital velocity near the surface were obtained by the AST system. The data were processed in STORMTM. Following the standard post-processing, the spikes were removed (mean $\pm 4 \sigma$, representing $0.006 \%$ of the dataset considering a normal distribution).

\section{WAVE RUN-UP}

Between August $20^{\text {th }}$ and September $21^{\text {st }}$, (19 field work days), during the time the AWAC ${ }^{\mathrm{TM}}$ was measuring waves, the wave run-up height was measured at Itapocorói Bay with a real time kinematic (RTK) GPS Trimble R6 and a data logger. In August the field work days were 
$20^{\text {th }}, 22^{\text {th }}, 24^{\text {th }}, 26^{\text {th }}, 29^{\text {th }}$ and $31^{\text {st }}$, in September on $2^{\text {nd }}$, $5^{\text {th }}, 12^{\text {th }}, 14^{\text {th }}, 16^{\text {th }}, 19^{\text {th }}$ and $21^{\text {th }}$. Firstly seven points of measurement were chosen in order to have data in both, protected and exposed areas. From September $12^{\text {th }}$ a new point was added in order to fill the gap between measurement points (see Figure 1). A base station was deployed to enable real time data collection using a roving staff. At each point the maximum up-rush of each wave was measured during a 30 minute campaign (Figure 2). The data were collected refered to the Imbituba vertical datum - default reference level in Brazil = approximatelly mean sea level at Imbituba, city located $170 \mathrm{~km}$ South - $28^{\circ} 14^{\prime} \mathrm{S}, 48^{\circ} 40^{\prime} \mathrm{W}$ - of study area), therefore, it was necessary to correct the measured elevations to the still water level, as proposed by HOLMAN (1986). To do that, the AWACTM pressure time series were used. The mean sea level (equal to Imbituba vertical datum mean sea level) was assumed to be equal to the mean sea level of the 34 days of mooring. The instantaneous sea level was subtracted from the instantaneous wave run-up to derive the wave run-up with respect to still water level.

\section{TOPOGRAPHY}

At the same location and each time that wave run-up measurements were conducted, a sub-aerial beach profile was measured using a Total Station TOPCON GPT-7500. The total station was placed where it could see two known points, enabling triangulation to obtain its position. To survey exactly the same profile the azimuth of each profile was defined and stakes were placed to guide the surveyor. The data were post-processed and reduced to Imbituba vertical datum. The profile data was used to calculate the beach face slope.

\section{BATHYMETRY}

Bathymetric data were obtained on November 2 and 6 of 2011 with a sub-metric precision Garmim GPSMAP 178c echo sounder and a DGPS Trimble R6 (centimeter precision), a laptop to record the data and a jetski. The equipment setup together with jetski vertical movements lead to a survey with errors $<1 \mathrm{~m}$. The Survey plan covered an approximate length of $300 \mathrm{~km}$ over an area of approximately $70 \mathrm{~km}^{2}$ with $300 \mathrm{~m}$ spacing between lines in the more exposed north of the bay and $100 \mathrm{~m}$ in the more protected south and around the islands. A DGPS was used in a PPK (Post Processed Kinematic) mode to post-correct the position based on two IBGE Continuum Monitoring Brazilian Network of GNSS Systems bases located $160 \mathrm{~km}$ south (Imbituba) and $150 \mathrm{~km}$ north of the study area (Curitiba). During the measurements, a gauge was installed at Picarras Inlet $(200 \mathrm{~m}$ from the furthest part of the West jetty) so the tide influence could be post-corrected. Spikes were taken out of the data visually considering the neighboring data. Two lines that presented several inconsistencies were discarded. As a heave compensator was not available in the survey, the height frequency oscillations caused by waves were filtered using a low-pass filter of $7^{\text {th }}$ order (considering 7 samples) for all surveyed lines. All bathymetry were collected in WGS-84 horizontal datum and referred to IBGE vertical datum.

\section{Tests of Existing Formulations}

In order to assess the performance of previous published empirical models, run-up data from the Itapocorói Bay tests were compared with predicted run-up. The wave run-up was measured and $\mathrm{R}_{2 \%}$ was calculated to compare the results using the following formulae:

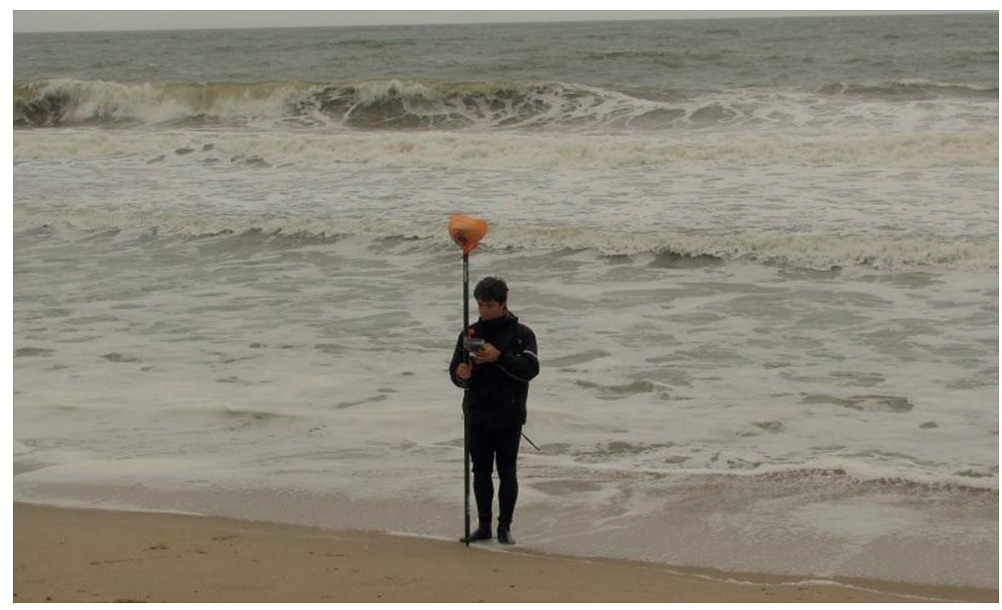

Figure 2. Maximum and instantaneous up-rush measurement on the beach face. 
a) NIELSEN; HANSLOW (1991)

b) STOCKDON et al. (2006)

c) GUZA; THORTON (1982)

To calculate run-up with GUZA; THORTON (1982) formula, the wave height measured at station ST003 during the field experiment described above were used (see Figure 1). On the other hand, both NIELSEN; HANSLOW (1991) and STOCKDON et al. (2006) formulas require wave height and length values at deep water. Therefore, deep water wave parameters for the study period were obtained from the WW3 model. The deep-water data was from a $200 \mathrm{~m}$ depth point seaward of the study area (X: -46.6324 Y:-26.6107). The wave data time series of these points are shown in Figure 3:

The existing models to calculate the run-up exceeded by $2 \%$ of the waves were then applied to each run-up measurement point in Itapocorói Bay.

\section{NUMERICAL MODELING}

To assess the wave data over the entire bay, it was necessary to conduct a wave modeling study. The bathymetry used consisted of the bathymetry presented above extended seaward using nautical chart number 1809 from DHN (Directorate of Hydrography and Navigation - Brazilian Navy). All the source data were referred to Imbituba vertical datum. A spherical coordinate grid (Figure 4) with 211 x 306 elements with spacevarying resolution (from approximately $210 \times 210 \mathrm{~m}$ in deeper parts to 20x20 m closer to the beach) was used for modeling wave transformation using SWAN (BOOIJ et al., 1999). The grid was extended to consider the effects of refraction and wave attenuation generated by southern headland.

The ST003 full directional spectrum obtained from

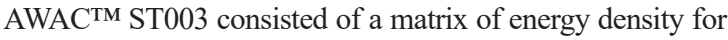
each time with 48 frequency bins and 90 directional bins. The ADCP output file was transformed into a SWAN input file, to run the model. The model considered 90 direction bins and 48 frequency bins as well as depth-induced breaking, bottom friction, diffraction, refraction and frequency shift. The calibration parameters used are presented in Table 1 .

From the calibrated wave model, the breaker wave height was identified as the point at cross-shore transects along beach where the Hs/depth ratio reaches a value of 0.5 (BERTIN et al., 2008; HARLEY et al., 2011). Transects were taken perpendicular to the coast in front of the points where the run-up measurements were conducted. At each transect, the break point was identified as a point where the ratio of $0.5(\mathrm{Hs} / \mathrm{depth})$ is reached.

\section{RESULTS AND DISCUSSION}

\section{RUN-UP AND MORPHODYNAMIC EXPERIMENT WAVES}

No signal-to-noise data presented a ratio lower than 30 , so all data was considered of good quality. After that
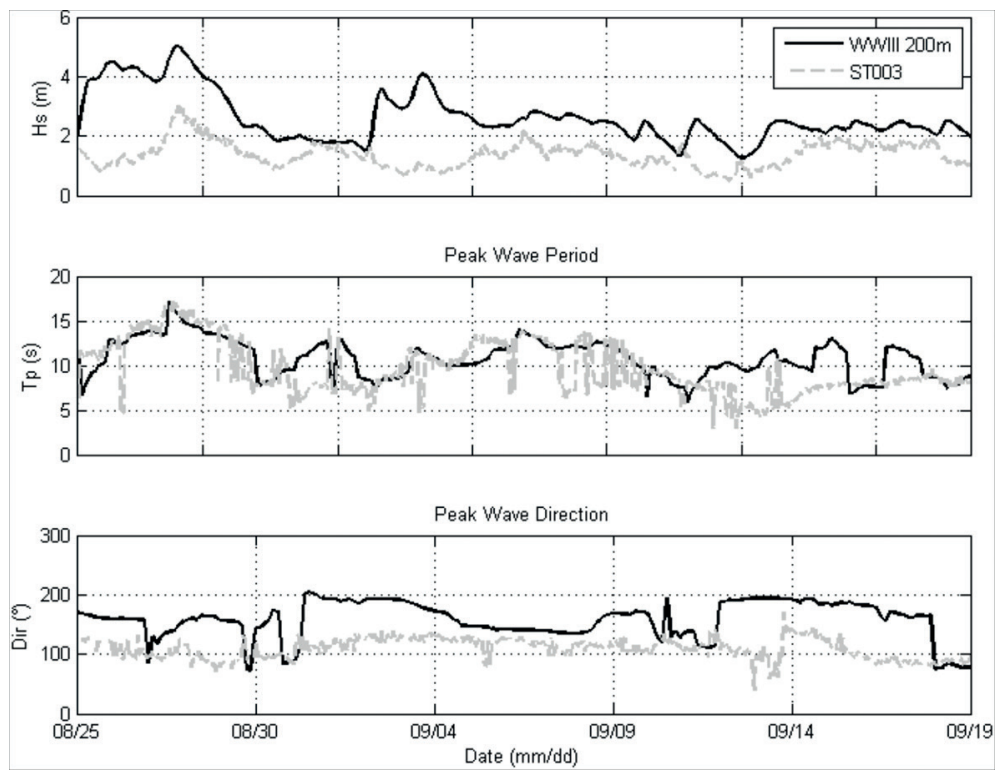

Figure 3. Wave data time series used to calculate wave run-up using existing models. WWIII=hindcast waves from NOAA website. ST003=measured wave parameters at Station ST003 (see Figure 1) 


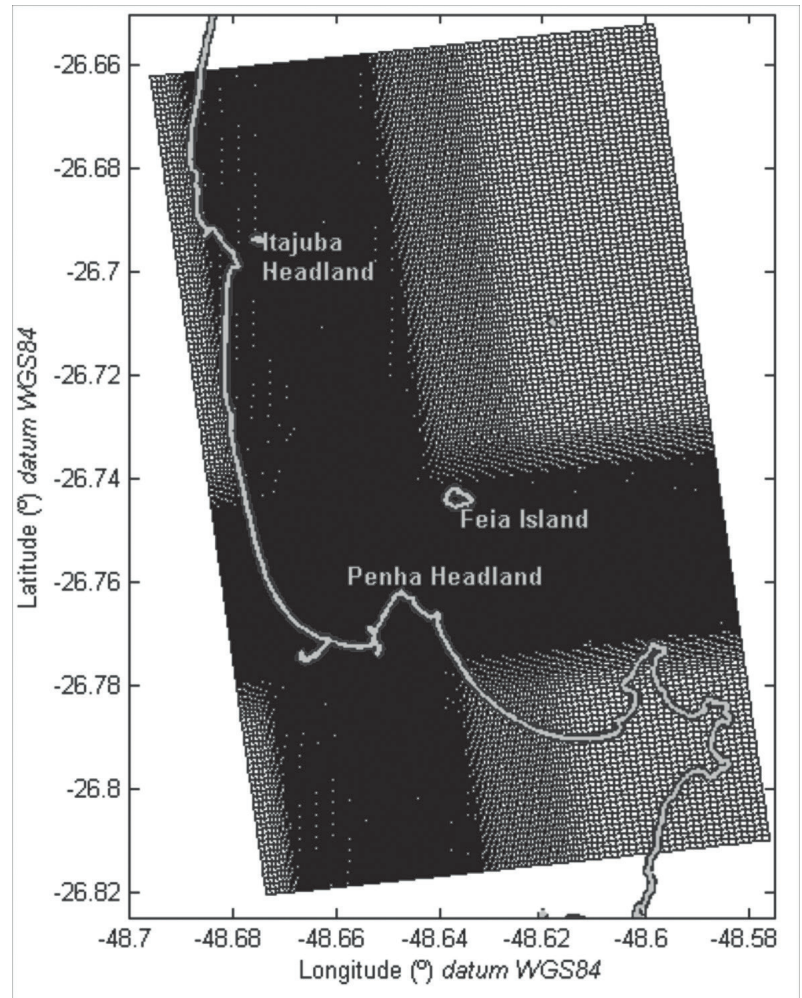

Figure 4. Wave grid used in SWAN wave-modeling exercise.

Table 1. Calibration Parameters used in SWAN model.

\begin{tabular}{lc}
\hline Parameter & Value \\
\hline Depth-induced Breaking (B\&J model) alpha & 1 \\
Depth-induced Breaking (B\&J model) Gamma & 0.73 \\
JONSWAP Bottom Friction & 0.04 \\
Difraction Smoothing coef. & 0.2 \\
Difraction Smoothing steps & 5 \\
\hline
\end{tabular}

analysis and after the qualification procedure described above, the final timeseries for all three ACDP's were plotted (Figure 5). After the post-processing the amount of recovered data for all ACDP's was higher than $95 \%$ of total possible data.

Wave parameters from ST003 were propagated and it was possible to notice that during the measurements when there was bimodal wave field (i.e. more energetic waves from south and less energetic waves from east) the calibration was poor. This occurs because the peak direction would normally be from south, however, for the protected southern part of the bay, the southerly waves are refracted/diffracted as they pass Penha headland and are considerably reduced in energy. The less energetic waves from east do not lose energy due to refraction/diffraction and reach the southern part of the bay with higher energy than would be considered by a theoretical spectrum shape such as JONSWAP.

The ST003 station received the highest waves (up to $3 \mathrm{~m}$ ) during the study period. Waves at ST002 were approximately $50 \%$ smaller as it is at a more protected area, and at ST001, waves were even smaller (around 50\% of ST002 height). Wave direction analysis indicated that waves were refracted/ diffracted as they entered the bay, varying in direction from $\sim 110^{\circ}$ (ST03) to $\sim 80^{\circ}$ (ST02) and $\sim 0^{\circ}$ (ST01). On August 26th the mean wave period in ST003 was around $7 \mathrm{~s}$, although, ST001 and ST002 presented a mean wave period of approximately $5 \mathrm{~s}$. That is again because of a bimodal condition (shorter period easterly waves together with longer period SE waves). Southeast waves that reach ST003 lose a considerable amount of energy due to refraction (bottom) and diffraction (Penha headland) as they propagate towards ST001 and ST002. On the other hand, easterly waves lose less energy due to refraction/diffraction processes as they propagate towards ST01 and ST02.

\section{WAVE RUN-UP}

An example of one wave run-up survey day (September $\left.12^{\text {th }}, 2011\right)$ is presented in Figure 6 . The $\mathrm{x}$-axis represents 

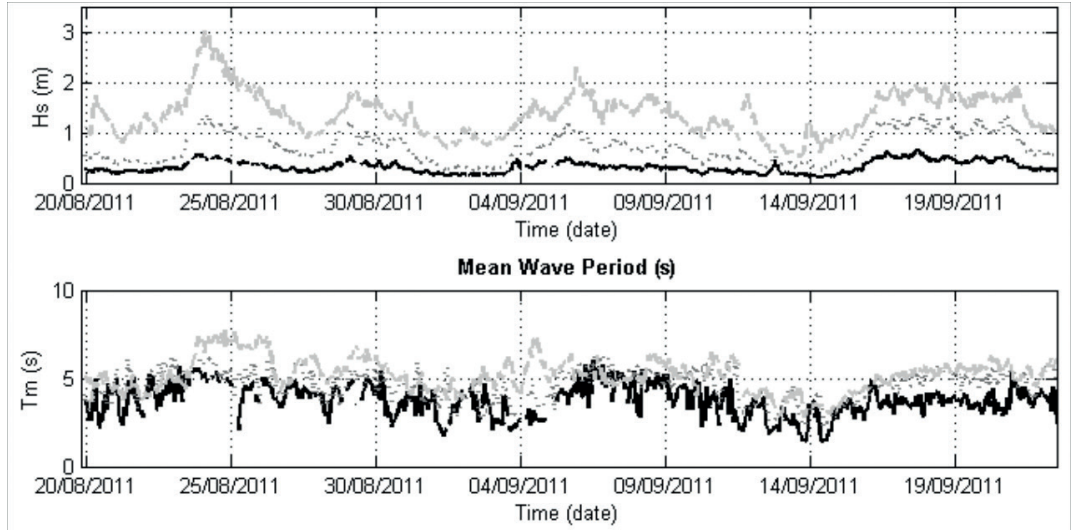

Mean Wave Direction (?)

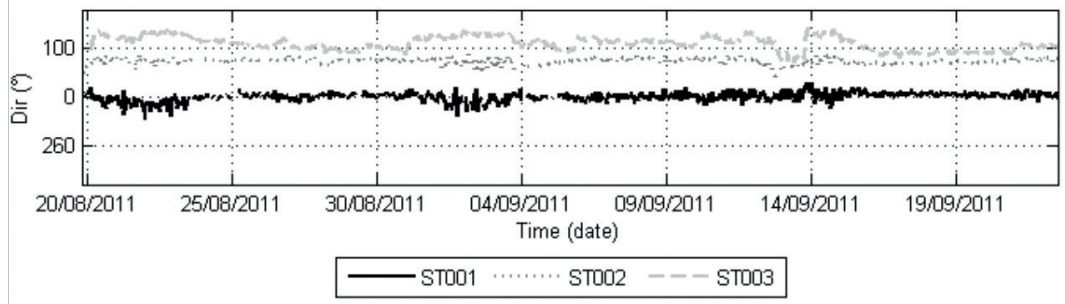

Figure 5. Measured wave parameter time series acquired with moored ADCP in Itapocorói Bay at depths of $3.9 \mathrm{~m}$ (ST001), $7.3 \mathrm{~m}$ (ST002) and $16.8 \mathrm{~m}$ (ST003).

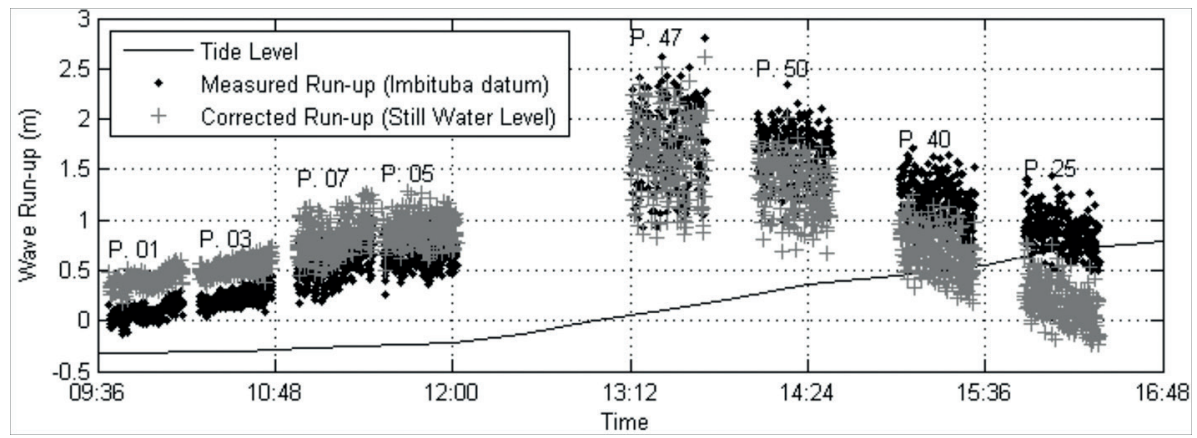

Figure 6. Example of run-up measured at each beach profile (figure 3) referenced to Imbituba vertical datum, tide level and corrected run-up (above still water level) for September, $9^{\text {th }}, 2011$.

the time of the measurement, the y-axis represents the runup level (tide, measured and corrected run-up). Each dot represents one measured run-up event reduced to Imbituba datum. Crosses refer to corrected run-up relative to still water level (Reducing the wave run-up to still water level datum is important in order to discount the influence of the tide in wave run-up heights). It is clear that the runup heights range increase in more exposed sections of the beach. In the protected part of the bay, the waves are more than $50 \%$ smaller than the exposed section, so the range of wave run-up is also smaller (0.25-0.7 m), than on exposed parts of the beach (1-1.5 m).

\section{BEACH PROFILE}

Topographic data were used to obtain the beach face slope. Figure 7 presents the beach profile measurements during the study period. The beach face slope was measured between the lowest and highest wave run-up at each site, and the tangent calculated for the intervening section.

\section{TESTS OF EXISTING RUN-UP FORMULAE}

Figure 8 shows the relation between the values of significant run-up (the run-up exceeded by $1 / 3$ of waves $-R_{s}$ ) calculated using GUZA; THORTON (1982) and NIELSEN; 


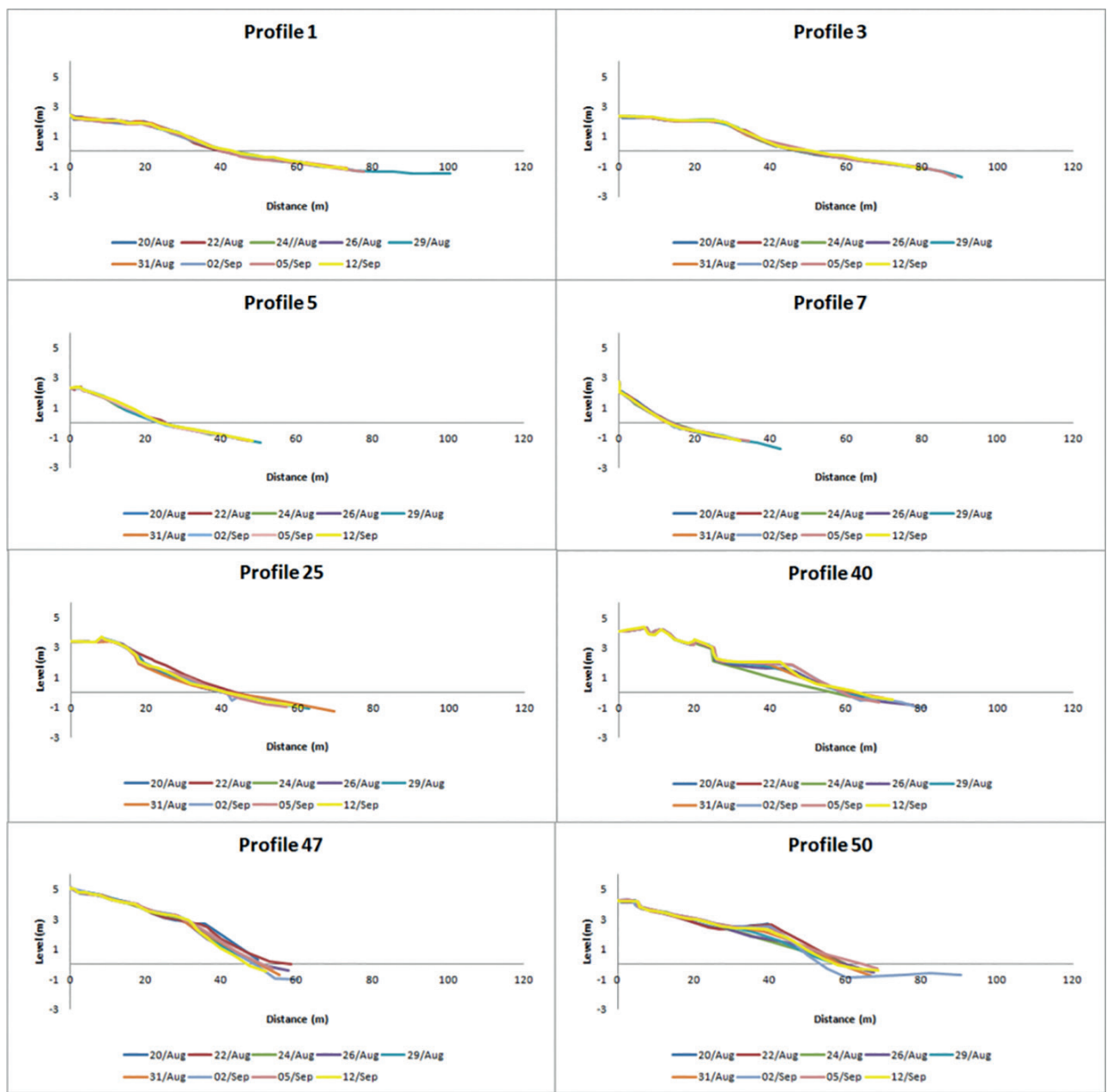

Figure 7. Monitoring of the morphological variations of the beach face slope at eight locations along Itapocorói Bay.
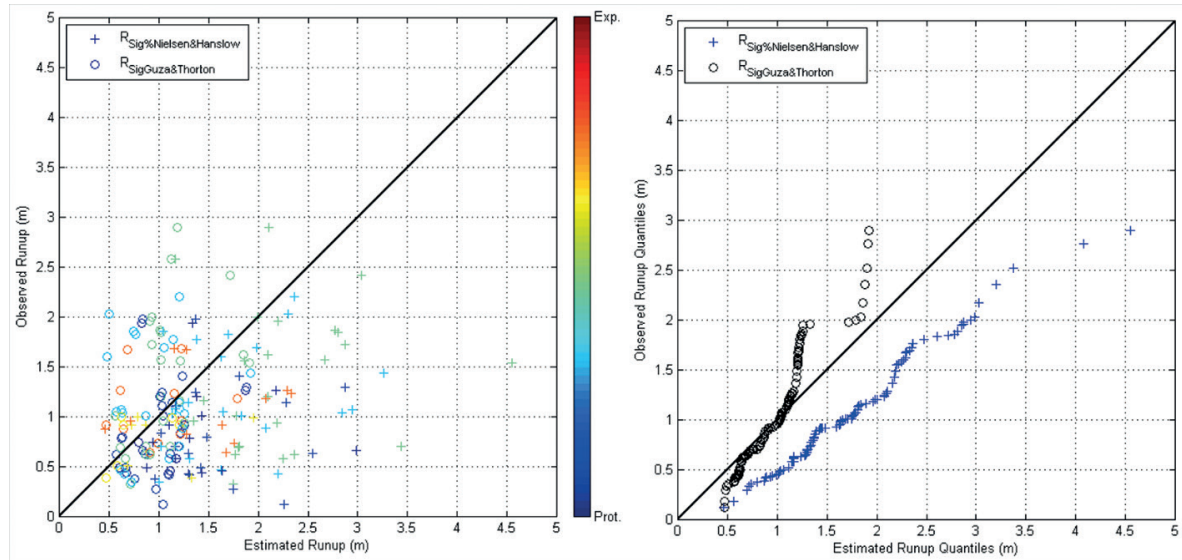

Figure 8. Comparison between observed significant wave run-up and the significant wave run-up calculated with the formulae of NIELSEN; HANSLOW (1991) - crosses and GUZA; THORTON (1982) - circles. (a) significant wave run-up/wave run-up estimation; (b) quantile/quantile. 
HANSLOW (1991) formulations, and the significant runup measured. Figure 9 compares the $\mathrm{R}_{2 \%}$ run-up calculated using NIELSEN; HANSLOW (1991) and STOCKDON et al. (2006). The graphs show an overestimation of the values of $R_{s}$ and $R_{\text {Sig }}$ by available formulation for the study area, especially at sheltered zone. Table 2 presents statistical parameters of the analysis. The significant wave run-up calculated by NIELSEN; HANSLOW (1991) formula were statistically different from the measured data. The GUZA; THORTON (1982) formula, on the other hand, was not statistically different to measured data with a significance level of 5\%. The NIELSEN; HANSLOW (1991) formula tends to overestimate the run-up. While GUZA; THORTON's (1982) formula represents run-up between 0.5 and $1.2 \mathrm{~m}$ quite well it underestimates values lower than 0.5 and overestimates values higher than 1.2 m. The formulae of NIELSEN; HANSLOW (1991) and STOCKDON et al. (2006) presented similar predictions of run-up 2\%, although, both formulae overrestimated R2\% for all measured data. For both formulae, with a level of significance of 0.05 , the means are statistically different from the measured data.
Considering that none of the tested equations fits the measured data, a new approach was taken that may be more applicable in embayed beaches.

A wave run-up formula suitable for either protected or exposed areas was developed using post- refraction / diffraction wave parameters, since these lead to variable wave heights along the bay (higher waves in exposed areas and smaller in protected areas). Breaker wave parameters are the more adequate to analyze wave run-up since at the break point the wave has already undergone most of the refraction and diffraction processes. Considering that wave run-up is a function of wave height, wave length and beach slope (HUNT, 1959; NIELSEN; HANSLOW, 1991; RUGGIERO et al., 2004; STOCKDON et al. 2006), the wave data obtained from calibrated numerical simulations were used to calculate the surf similarity parameter according to:

$$
\xi_{b}=\frac{\tan \beta}{\sqrt{H_{b} / L_{0}}}
$$

where is $\mathrm{Hb}$ the mean $1 / 3$ highest waves at break, Lo and $\mathrm{L}_{0}$ is the deep water wave length.

$$
L_{0}=\frac{g}{2 \pi} T^{2}
$$
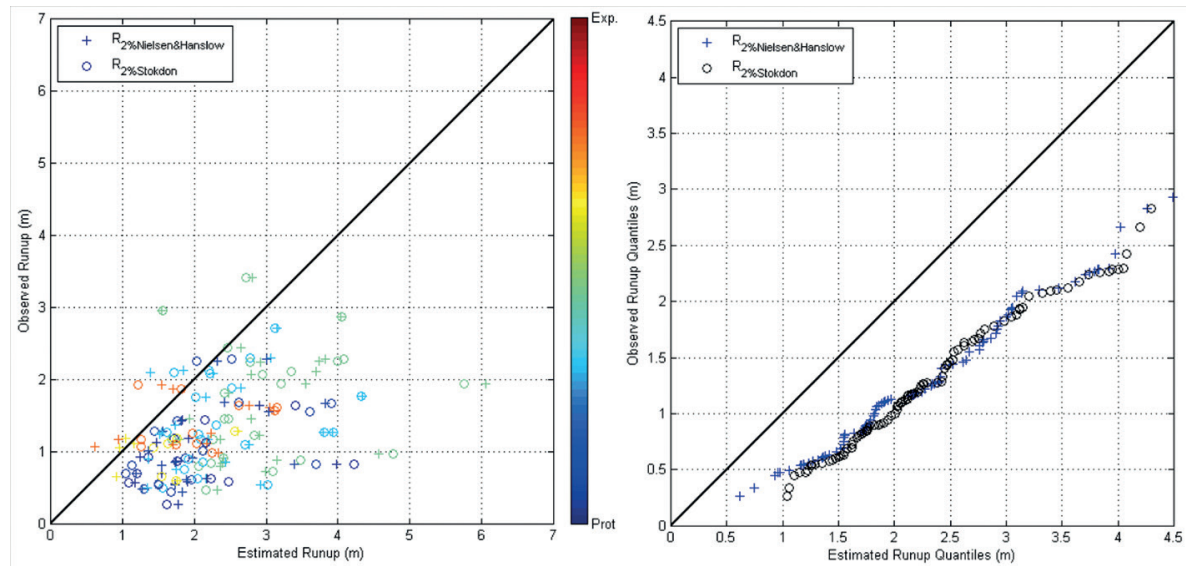

Figure 9. Comparison between observed R2\% and the R2\% calculated with the formulae of NIELSEN; HANSLOW (1991) - crosses and STOCKDON et al. (2006) - circles. (a) R2\% wave run-up; (b) quantile/quantile.

Table 2. Tested formulae versus measured data: statistical parameters.

\begin{tabular}{lcccccccc}
\hline \multirow{2}{*}{ Formula } & \multicolumn{3}{c}{ Data } & \multicolumn{3}{c}{ Quantile } \\
& $\mathrm{r}$ & $\mathrm{R}^{2}$ & $\mathrm{RMSE}$ & $\mathrm{P}$ & $\mathrm{r}$ & $\mathrm{R}^{2}$ & $\mathrm{RMSE}$ & $\mathrm{p}$ \\
\hline Rsig NIELSEN; HANSLOW (1991) & 0.28 & 0.08 & 1.01 & $4.54 \mathrm{E}-11$ & 0.99 & 0.98 & 0.69 & $1.61 \mathrm{E}-11$ \\
Rsig GUZA; THORTON (1982) & 0.28 & 0.08 & 0.58 & 0.17 & 0.96 & 0.92 & 0.28 & 0.16 \\
R2\% NIELSEN; HANSLOW (1991) & 0.39 & 0.15 & 1.36 & $1.10 \mathrm{E}-14$ & 0.99 & 0.98 & 1.07 & $2.56 \mathrm{E}-15$ \\
R2\% STOCKDON et al. (2006) & 0.37 & 0.14 & 1.40 & $1.26 \mathrm{E}-16$ & 0.99 & 0.99 & 1.11 & $1.89 \mathrm{E}-17$ \\
\hline
\end{tabular}


where $\mathrm{g}$ is the gravity and $\mathrm{T}$ is the mean wave period.

The surf similarity parameter and wave height were considered the main parameters to assess wave run-up, therefore it were plotted against measured $\mathrm{R}_{2 \%}$ and the linear coefficients were adjusted to fit the data. Furthermore, a quantile-quantile analysis was preformed to analyze the accuracy of the formula. To analyze the results four statistical parameters were applied: 1) Pearson coefficient (r) to identify the correlation between predicted and measured data; 2) Coefficient of determination $\left(\mathrm{R}^{2}\right)$ to analyze how well the data fits the model; 3) RMSE to access the error of the model and; 4) A student t-test was applied to test the hypothesis that both measured and calculated run-up have equal means. The test was applied with a significance level of 5\% and $p>0.05$ indicates that correlations are statistically valid.

\section{Model Results}

The calibrated timeseries for ST001 and ST002 are presented in Figure 10 and Figure 11, respectively. The model presented a Hs RMSE (root mean square error) of 0.07 and a $0.09 \mathrm{~m}$ for ST001 and ST002; mean wave period (T) RMSE of 2.03 (ST001) and $1.2 \mathrm{~s}$ (ST002); and direction RMSE of 10.69 (ST001) and $9.34^{\circ}$ (ST002).

\section{NEW FORMULA}

Wave parameters at the breakpoint, measured wave run-up and beach slope were used to find a set of formulae that fits the measured data for both protected and exposed part of an embayed beach. Table 3 presents a summary of the best fit equations for all calculated values of wave run-up and its Pearson coefficient (r), coefficient of determination $\left(\mathrm{R}^{2}\right)$, RMSE. A student t-test was analyzed with a significance level of $5 \%$. For all cases the Pearson coefficient, as expected, presented a positive correlation. The coefficient of determination showed that the data may be varying along the tendency with $\mathrm{R}^{2}$ varying between 0.27 and 0.56 but the quantile analysis showed that all the formula are very accurate with $\mathrm{R}^{2}$ of 0.98 or more in all cases. The RMSE for the data varied between $0.44\left(R_{2 \%}\right)$ and 0.65 (Rmax). The calculated RMSE for quantile analysis showed that all the formulae are very accurate with RMSE varying from $0.07 \mathrm{~m}$ for $\mathrm{R}_{\text {mean }}$ to $0.11 \mathrm{~m}$ for $\mathrm{R}_{\max }$. The analysis is considered statistically valid for all formulae for both data and its quantile.

The proposed equations provide very good predictions of wave run-up along an embayed beach (Figure 12) as it considers wave parameters at the break point, after the wave has already undergone refraction/ attenuation processes characteristic of embayed beaches. The results showed that all proposed formulae fit the measured data very well. The individual run-up errors may be related to errors of measurements, modeling and to nonlinear processes that swash zone is exposed to.

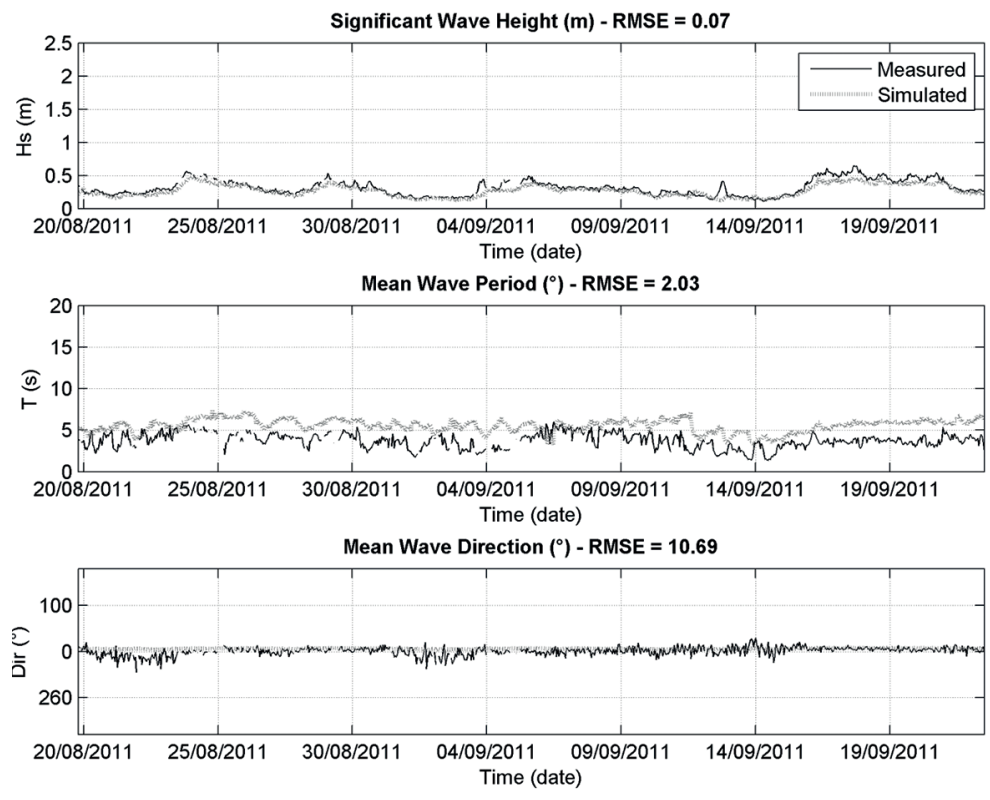

Figure 10. SWAN calibration at ST001. 

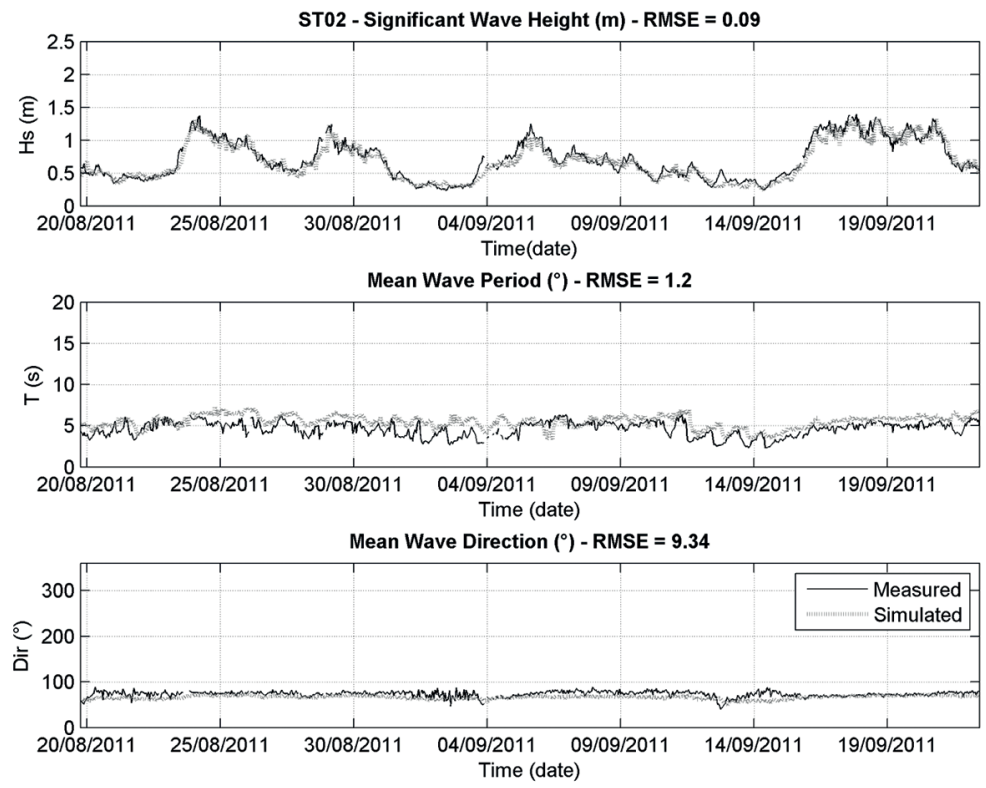

Figure 11. SWAN calibration at ST002.

Table 3. Proposed formulae and statistical parameters of its predictions.

\begin{tabular}{lcccccccc}
\hline Formula & \multicolumn{4}{c}{ Data } & \multicolumn{4}{c}{ Quantile } \\
& $\mathrm{r}$ & $\mathrm{R}^{2}$ & $\mathrm{RMSE}$ & $\mathrm{p}$ & $\mathrm{r}$ & $\mathrm{R}^{2}$ & $\mathrm{RMSE}$ & $\mathrm{p}$ \\
\hline$R_{\text {mean }}=H s_{b} \xi_{b}+0.1$ & 0.65 & 0.42 & 0.39 & 0.90 & 0.99 & 0.98 & 0.07 & 0.91 \\
$R_{\text {sig }}=1.3 H s_{b} \xi_{b}+0.1$ & 0.52 & 0.27 & 0.57 & 0.73 & 0.99 & 0.99 & 0.09 & 0.72 \\
$R_{2 \%}=1.35 H s_{b} \xi_{b}+0.32$ & 0.75 & 0.56 & 0.44 & 0.93 & 0.99 & 0.98 & 0.09 & 0.92 \\
$R_{\text {max }}=1.6 H s_{b} \xi_{b}+0.35$ & 0.59 & 0.35 & 0.65 & 0.84 & 0.99 & 0.98 & 0.11 & 0.85 \\
\hline
\end{tabular}
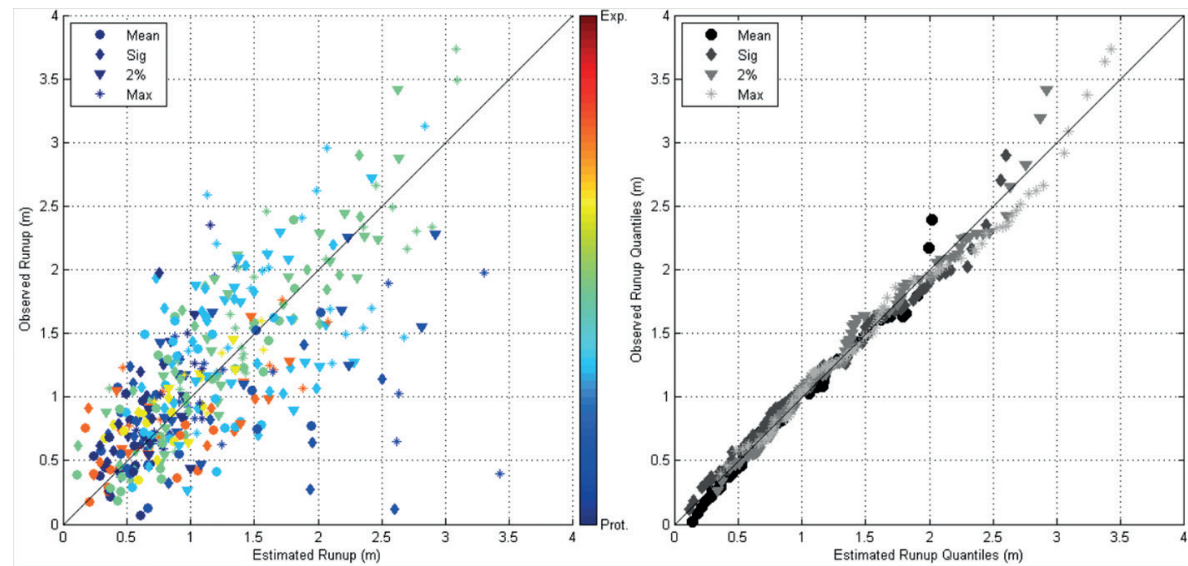

Figure 12. Estimated wave run-up vs observed wave run-up (left) and its quantiles (right) for mean (square), significant (diamond), 2\% (circle) and maximum (cross). The colors represent the degree of exposure of the measurement site. 


\section{CONCLUSION}

On protected beaches the available formulae to predict $\mathrm{R}_{\text {sig }}$ and $\mathrm{R}_{2 \%}$ are not in good agreement with wave runup measured. That is due to reliance on wave deep water parameters that do not reflect conditions in embayed beaches where shallow water transformations create strong wave-energy variations along the beach.

This paper presents formulae to calculate run-up for embayed beaches. The formulae are based on measured data from intensive field work, and, are presented as appropriate for other embayed beaches. In contrast to the other formulae that use deepwater wave parameters, the formulae presented here are suitable for beaches where the wave conditions vary alongshore. It considers waves that have already passed through most transformation processes such as refraction and diffraction before reaching the break point. For that reason the proposed formula fits the entire bay and does not overestimate the wave run-up on sheltered parts of the beach or underestimate in exposed areas.

The proposed formula is in good agreement with measured data for a variety of wave conditions and degrees of protection. The analysis demonstrates that even with $\mathrm{R}^{2}$ varying from 0.52 to 0.75 , the measured distribution of measured and modeled wave run-up are very consistent, as shown by quantile/quantile analysis with $\mathrm{R}^{2}$ of 0.98 to 0.99 . The individual run-up errors may be related to errors of measurements, modeling and to non-linear processes that swash zone is exposed to, such as infragravity waves.

\section{ACKNOWLEDGEMENTS}

The authors are very thankful to CNPq-CTTrans Proc. No.575008/2008-3, CNPq Research Productivity Scholarship, CAPES-RISCOS for a scholarship, PPGEOUFRGS, PPGG-UFSC, UNIVALI for all field support, CB\&I Brazil for ADCP mooring and data processing support, "Anjos do Mar" for jetski bathymetry support, to all the team that worked at the field: Ácmon Bhering, Alexandre Schweitzer, Camila Longarete, Diego Bitencourt, Francisco Travassos, Felipe Amorim, Jonas Oliveira, José Neto, Mar Alfaro, Marcos Berribilli, Michel Prado. Without this support this paper would not have been possible.

\section{REFERENCES}

AHRENS, J. P.; TITUS, M. F. Wave runup formulas for smooth slopes. J. Wat. Port, Coast. Ocean. Eng., v. 111, n. 1, p. 128$133,1985$.
ARAÚJO, C. E. S.; FRANCO, D.; MELO, E.; PIMENTA, E. Wave regime characteristics of the southern Brazilian coast. In: International Conference on Coastal and Port Engineering in Developing Countries, 6., 2003, Colombo, Sri Lanka. Proceedings. Colombo: COPEDEC VI, 2003. 15 CD-ROM.

ARAÚJO, R. S.; SPROVIERI, F. C.; FREITAS, D.; KLEIN, A. H. F. Variação da morfologia praial e identificação de zonas de erosão acentuada (ZEA) na enseada do Itapocorói - SC. Braz. J. Aquat. Sci. Technol., v. 14, n. 1, p. 29-38, 2010.

BATTJES, J. A. Computation of set-up, longshore currents, runup and overtopping due to wind-generated waves. 1974. 251f. Thesis (Doctoral) - Committee on Hydraulics. Civil Engineering and Geoscience, Delft University of Technology. Delft, 1974. http://repository.tudelft.nl/islandora/object/ uuid:e126e043-a858-4e58-b4c7-8a7bc5be1a44? collection=r esearch

BATTJES, J.A.; JANSSEN, J.P.F.M. Energy loss and set-up due to breaking of random waves. Proc. Coast. Eng., ASCE, p. 569-587, 1978.

BERTIN, X.; CASTELLE, B. O.; CHAURNILLON, E.; BUTEL, R.; QUIQUE, R. Longshore transport estimation and interannual variability at a high-energy dissipative beach: $\mathrm{St}$. Trojan beach, SW Oléron Island, France. Cont. Shelf Res., v. 28, n. 10-11, p. 1316-1332, 2008.

BONETTI, J.; KLEIN, A. H. F.; MULER, M.; DE LUCA, C. B.; SILVA, G. V.; TOLDO JR., E. E.; GONZÁLEZ, M. Spatial and numerical methodologies on coastal erosion and flooding risk asserssment. In: FINKL, C. (Ed.). Coastal hazards. Chapter 16. Coastal Research Library Series. Dordrecht: Springer, 2012. p. 423-442.

BOOIJ, N.; RIS, R. C.; HOLTHUIJSEN, L. H. A third-generation wave model for coastal regions: 1 . Model description and validation. J. Geoph. Res., v. 104, n. C4, p. 7649-7666, 1999.

CASTRO, B. M.; LEE, T. N. Wind-forced sea level variability on the southeast Brazilian shelf. J. Geoph. Res., v. 100, n. C8, p. 16045-16056. 1995

GUZA, R. T.; THORTON, E. B. Swash oscillations on a natural beach. J. Geoph. Res., v. 87, n. C1, p. 483-491. 1982.

HARLEY, M. D.; TURNER, I. L.; SHORT, A. D.; RANASINGHE, R. A reevaluation of coastal embayment rotation: The dominance of cross-shore versus alongshore sediment transport processes, Collaroy-Narrabeen Beach, Southeast Australia. J. Geoph. Res., v. 116, F04033, 2011.

HOLMAN, R. A. Extreme value statistics for wave run-up on a natural beach. Coast. Eng., v. 9, n. 6, p. 527-544. 1986.

HEDGES, T. S.; MASE, H. Modified Hunt's equation incorporating wave setup. J. Wat. Port Coast. Ocean. Eng. v. 130, n. 3, p. 109-113, 2004.

HOLLAND, K. T.; RAUBENHEIMER, B.; GUZA, R. T., HOLMAN, R. A. Runup kinematics on a natural beach. $J$ Geoph. Res., v. 100, n. C3, p. 4985-4993, 1995

HOLMAN, R. A. Extreme value statistics for wave runup on a natural beach. Coast. Eng., v. 9, n. 6, p. 527-544, 1986.

HOLMAN, R. A.; SALLENGER JR, A. H. Setup and swash on a natural beach. J. Geoph. Res., v. 90, n. C1, p. 945-953, 1985.

HORIKAWA, K. Nearshore Dynamics and Coastal Processes: Theory, Management, and Predictive Models. Tokyo: University of Tokyo Press, 1988. 522 p. 
HUNT, I. A. Design of seawalls and breakwaters. J. Wat. Harb. Div., v. 85, p. 123-152, 1959.

KLEIN, A. H. F.; MENEZES, J. T. Beach morphodynamics and profile sequence for headland bay coast. J. Coast. Res., v. 17 n. 4, p. 812-835, 2001.

KLEIN, A. H. F.; FERREIRA, Ó.; DIAS, J. M. A.; TESSLER, M. G.; SILVEIRA, L. F.; BENEDET, L.; DE MENEZES, J. T.; DE ABREU, J. G. N. Morphodynamics of structurally controlled headland-bay beaches in southeastern Brazil: A review. Coast. Eng., v. 57, n. 2, p. 98-111, 2010.

LONGO, S.; PETTI, M.; LOSADA, I. J. Turbulence in the swash and surf zones: a review. Coast. Eng., v. 45, n. 3-4, p. 129$147,2002$.

LOUREIRO, C.; FERREIRA, O.; COOPER, J.A. G. Applicability of parametric beach morphodynamic state classification on embayed beaches. Mar. Geo., v. 346, p. 153-164, 2013.

NIELSEN, P. Wave setup and runup: An integrated approach. Coast. Eng., v. 13, n. 1, p. 1-9, 1989.
NIELSEN, P.; HANSLOW, D. J. Wave runup distributions on natural beaches. J. Coast. Res., v. 7, n. 4, p. 1139-1152, 1991.

RUGGIERO, P.; HOLMAN, R. A.; BEACH, R. A. Wave run-up on a high-energy dissipative beach. J. Geoph. Res., v. 109, n. C6, 2004.

STOCKDON, H. F.; HOLMAN, R. A.; HOWD, P. A.; SALLENGER JR, A. H. Empirical parametrization of setup, swash and runup. Coast. Eng., v. 53, n. 7, p. 573-588, 2006.

TRUCCOLO, E. C.; FRANCO, D.; SCHETTINI, C. A. F. The low frequency sea level oscillations in the Northern Coast of Santa Catarina, Brazil. J. Coast. Res., SI 39, p. 547-552, 2004.

VIEIRA DA SILVA, G.; TOLDO JR, E. E.; KLEIN, A. H. F.; SHORT, A. D.; WOODROFFE, C. D. Headland sand bypassing - quantification of net sediment transport in embayed beaches, Santa Catarina Island North Shore, Southern Brazil. Mar. Geo., v. 379, p. 13-27, 2016. 